RESEARCH ARTICLE

\title{
The Loss of the Native Language and Post-Imperial Narratives
}

\section{(Yeats and Joyce)}

Dr. Fedya Daas

ISLT (High Institute of Languages in Tunis) (Tunisia)

\begin{abstract}
:
This article addresses the issue of language in colonial and post-colonial contexts and its role in delineating authentic features of national identity. The first part tackles African and Irish theorists such as Ngugi wa Thiong'o and Douglas Hyde whose views of clinging to the native tongue promote the politics of an essentialist identity. According to them, the loss of the native language brings about feelings of inferiority and estrangement which serve only to empower the colonizer. The article, then, proceeds to more tolerant writers who believe in the colonizer's share in the making of the present of the colonized and favor hybrid identities. For them, it is impossible to reduce the polyvocality of the moment into the too-familiar, too-reassuring fictions of the old days. Finally, this work focuses on the Irish context through Yeats and Joyce who radically transform the idea of the nation theorizing for style as an agent of redemption from colonial artistic and political confines. Their cosmopolitan techniques allow the breakthrough of a new context, a post-imperial writing. The loss of the native language, therefore, opens alternative artistic paths to experiment with the language of the colonizer fostering a modern, cosmopolitan and continuously changing "national" identity.
\end{abstract}

Keywords: National identity, native language, essentialist, hybrid, experimentation, post-imperial

\section{Introduction:}

Appeals to the native language in colonial and post-colonial contexts are among the most common of strategies to recover one's indigenous identity. What animates such appeals is actually not only the consciousness that one's language is perishing and along it one's culture but that patterns of power become dependent upon the learning, speaking and writing in the imperial language. And therefore the native language is associated with narratives of loss and disablement. Hence, the retrieval of the language becomes a positioning and re-positioning of the colonial subject on the map of power. This problem raises automatically the discussion about what language should be deployed by the subject people and especially in national literature to construct one's national consciousness.

\section{Discussion and Analysis:}

\subsection{Rejecting the Colonizer's Language:}


Ngugi wa Thiong'o (1986) in his Decolonising the Mind stresses the importance of using one's native language in the process of independence and post-independence to secure a fully African identity. He explains the workings of language in the politics of cultural identity:

Language carries culture, and culture carries, particularly through orature and literature, the entire body of values by which we come to perceive ourselves and our place in the world. How people perceive themselves and affects how they look at their culture, at their politics and at the social production of wealth, at their entire relationship to nature and to other beings. Language is thus inseparable from ourselves as a community of human beings with a specific form and character, a specific history, a specific relationship to the world. (p.16)

Here language overwhelms its communicative function: not only our personal, historical and social specificities are mapped in language and through language but the entirety of our being is determined by our linguistic faculty. Excluding all other modes of self-perception, Thiong'o posits language as the sole mode of perceiving ourselves, others and our inter-relations, theorizing for an organic relationship between language and the self. He, consequently, laments the identification of postcolonial writings with European languages which are glorified and posited as points of references wherein the task of the native writer was to dismantle these myths of the European language centrality:

African countries, as colonies and even today as neo-colonies, came to be defined and to define themselves in terms of the languages of Europe: English-speaking, French-speaking or Portuguese-speaking African countries...Unfortunately writers who should have been mapping paths out of that linguistic encirclement of their continent also came to be defined and to define themselves in terms of the languages of imperialist imposition. (Thiong'o, 1986, p.5)

Thiong'o (1986) points out that the obliteration of the native language is a deliberate scheme from the part of the colonizer which aims at but also achieves a permanent distortion and destabilization of the coherence of the colonial subject. It is a beheading of the natives and a defilement of their pure nativism through forcibly mingling two heterogeneous linguistic

entities. He further clarifies:

Colonial alienation takes two interlinked forms: an active (or passive) distancing of oneself from the reality around; and an active (or passive) identification with that which is most external to one's environment. It starts with a deliberate disassociation of the language of conceptualization, of thinking, of formal education, of mental development, from the language of daily interaction in the home and in the community. It is like separating the mind from the body so that they are occupying two unrelated linguistic spheres in the same person. On a larger social scale it is like producing a society of bodiless heads and headless bodies. (p.28)

Thiong'o's view is shared by David Diop (1956) who sees that relinquishing the native language is an enslaving modern strategy from the part of the colonizer and an up-rooting of the natives, a neoclassical project par excellence:

The African creator, deprived of the use of his language and cut off from his people, might turn out to be only the representative of a literary trend (and that not necessarily the least gratuitous) of the conquering nation. His works, having become a perfect illustration of the assimilationist policy through imagination and style, will doubtless rouse the warm applause of a certain group 
of critics. In fact, these praises will go mostly to colonialism which, when it can no longer keep its subjects in slavery, transforms them into docile intellectuals patterned after Western literary fashions which besides, is another more subtle form of bastardization. (p.114)

The quote exposes the politics of an essentialist identity that is formed around opposites, colonizer versus colonized, a "conquering nation" versus a conquered one, masters versus slaves, originals versus imitation, agents versus passives and nobles versus bastards. Obi Wali joins the chorus of the exponents of nativist languages linking nativism to advancement: "the whole uncritical acceptance of English and French as the inevitable medium for educated African writing is misdirected, and has no chance of advancing African literature and culture" (qtd in Thiong'o, 1986, p.24). Thiong'o moves a step forward and posits nativism the very condition of liberation since "African languages addressing themselves to the lives of the people become the enemy of a neo-colonial state" (p.30).

In the Irish context, Douglas Hyde in his lecture "The Necessity of De-Anglicizing Ireland" "delivered to the Irish Literary Society in November 1892" which "led within a year to the foundation of the Gaelic league, a movement for the preservation of Irish" (Kiberd, 1996, p.140) voices his fears of losing the Irish language. According to him, such a loss will shatter all hopes of the restoration of the "Irish race" and the "Gaelic nation" as the Irish will find themselves "despoiled of the bricks of nationality" namely their "language, traditions, music, genius, and ideas" (Hyde, 1904).

Though the nativists' calls are benevolent in their intentions, the fanatic clinging to the pure language of the natives in a now-hybridized community is very intricate if not impossible. The danger is that the nativists will always seek a pure past, a pristine language and heritage that existed so to speak in the pre-colonial times, reducing the polyvocality of the moment back into the too-familiar, too-reassuring fictions of the old days. Besides, in these calls, the all-too-omnipresent danger is the imitation of the colonizer's logic of binarism and therefore the embracing of what they claim to refute. Ania Loomba (1998) brilliantly captures the idea warning that in "the process of exposing the ideological and historical functioning of such binaries, we are in danger of reproducing them" (p.104).

\subsection{The Necessity of Using the Colonizer's Language:}

The practice of writing in the language of the colonizer, however, is deemed justifiable and even national for writers who believe in the inevitable reciprocity by which the experience of the colonized is bound to that of the colonizer. No matter how ironically Thiong'o refers to this idea as "the fatalistic logic", the share of the colonizer in the making of the present of the colonized is undeniable. Chinua Achebe, for example, while euphemistically acknowledging the guilt of forsaking one's native language, sees the deployment of the colonizer's language as a necessity. If abandoning the mother tongue is a betrayal, writing in English is an obligation. Achebe does not choose English, English chooses him. And he is grateful for the choice: "Is it right that a man should abandon his other tongue for someone else's? It looks like a dreadful betrayal and produces a guilty feeling. But for me there is no other choice. I have been given the language and I intend to use it" (Achebe, 1975, p.7). He also points to the possibility of writing about African experience in English: "I feel that the English language will be able to carry the weight of my African experience. But it will have to be a new English, still in full communion with its ancestral home but altered to suit new African surroundings". (p.7) The nativist writing task, therefore, turns into maintaining cultural national sovereignty while cultivating beneficial links with the English language. 
Gabriel Okra speaks about varieties of English: "There are American, West Indian, Australian, Canadian and New Zealand versions of English. All of them add life and vigour to the language while reflecting their own respective cultures. Why shouldn't there be a Nigerian or West African English which we can use to express our own ideas, thinking and philosophy in our own way?" (qtd in Thiong'o, 1986, p.9). Coming to tolerant terms with the language of the colonizer imposes itself as a necessity for generations who have been taught the imperial language at school and can use it as a literary medium. Often knowing nothing about their own native tongue, these people find it impossible to fully present themselves in a language other than English. Furthermore, owning a completely different cultural heritage from that of the Englishman, the colonized's deployment of English naturally imposes its own ways.

\subsection{Experimenting with the colonizer's language:}

Back to the Irish context, the situation is complex for "the Irish writer [who] has always been confronted with a choice. This is the dilemma of whether to write for the native audience - a risky, often thankless task - or to produce texts for consumption in Britain and North America" (Kiberd, 1996, p.136). For Yeats, the situation seems the most complicated of all because of his Anglo-Irish background. He confesses: "the English language in which I think, speak and write...everything I love has come to me through English; my hatred tortures me with love, my love with hate. I am like the Tibetan monk who dreams at his initiation that he is eaten by a wild beast and learns on working that he himself is eater and eaten" (Yeats, 1980, p.263).

Yeats, though aware of the Anglo-Irish crisis of identity does not believe that English as a language prevents the articulation of a national identity. Although he sees eye to eye with Hyde on what makes up a genuine nationality, namely the restoration of Gaelic games, music, traditions and heroes mentioned in the latter's lecture, he wonders whether placing the Irish language at the centre of Irishness makes of English-speaking Ireland "a nation of imitators" without "the power of native initiative and alive only to second-hand assimilation" (Hyde, 1904):

Is there, then, no hope for the de-anglicizing of our people? Can we not build up a national literature, which shall be none the less Irish in spirit from being English in language? Can we not keep the continuity of the nation's life, not by trying to do what Dr. Hyde has practically pronounced impossible, but by translating and retelling in English, which shall have an indefinable Irish quality of rhythm and style, all that is best in the ancient literature? Can we not write and persuade others to write histories and romances of the great Gaelic men of the past, from the son of Nessa to Owen Roe, until there has been made a golden bridge between the old and the new. (Yeats, 1970, p.255)

O' Brien discusses Yeats's peculiar notion of deanglicization that consists of writing about Irish themes in English and believes that "Yeats is offering a way out of the closed system of essentialist Irishness" (p.130). This leads to his encompassing description of Yeats as "the Anglo-Irish, Englishspeaking deanglicizer of Ireland" (p.135).

Yeats's project of deanglicization, then, consists of endowing his English verse with an Irish spirit, imbuing it with Irish rhythm and style and introducing great Gaelic men of the past. It becomes, therefore, clear that Yeats employs English to carry what he used to call the "Irish subject", Yeats 
succeeds not in reversing the hierarchy English/Gaelic but in asserting that "a self could only awaken by an act of hybridization" (Kiberd, 1996, p.165). Yeats's intense engagement with Irish old spirits by reporting, narrating, composing, unearthing, rediscovering and reviving the heritage of his people within the confines of the English language helps the emergence of a new "mode of expression" which "was nothing other than the search for a national style" (Kiberd, 1996, p.116) and an intelligent exploitation of the creative possibilities of the language. The word style for Yeats is highly connotative both aesthetically and politically; their very fusion is what enables "the idea of a nation" (Yeats, 1999, p.364).

Yeats's practices amount to what is described by Ashcroft (2002) in The Empire Writes Back as "abrogation or denial of the privilege of 'English' [which] involves a rejection of the metropolitan power over the means of communication [and] appropriation and reconstitution of the language of the centre, the process of capturing and remoulding the language to new usages, marks a separation from the site of colonial privilege" (p.37). He continues: "Appropriation is the process by which the language is taken and made to 'bear the burden' of one's own cultural experience, or, as Raja Rao puts it, to 'convey in a language that is not one's own the spirit that is one's own.' (Rao 1938:vii)" (p.38). Decland Kiberd (1996) brilliantly captures Yeats's practices in his article's title "Revolt into StyleYeatsian Poetics" considering style as "an agent of redemption" from English artistic as well as colonial shackles (p. 305).

The late Yeats moves a step forward from the simplistic form of appropriation and starts an enterprise of shattering old forms of dramaturgy by incorporating Japanese Noh techniques in an English-speaking Irish national theatre allowing the breakthrough of a new context, a post-imperial writing. From the bare stage that contrasts with the crammed space of the realistic European drama to the use of the mask and the adaptation of the concept of the anti-self which foreground the doubleness of character besides the presence of the musicians in his late plays who provide a commentary upon the symbolic events, the Japanese style of characterization and dramaturgy becomes the force by which Yeats moulds an Irish nativist lore within a foreign tradition to communicate personal and nationalistic themes. Yeats (1961) boasts: [w]ith the help of Japanese plays 'translated by Ernest Fenollosa and edited by Ezra Pound" I have invented a form of drama, distinguished, indirect and symbolic, and having no need of mob or Press to pay its way - an aristocratic form” (p. 221).

The enterprise is carried on extraordinarily by James Joyce who founds new narrative modes that use international English rather than English or Irish English permitting the emergence of a cosmopolitan identity. If the national literature is but a conflict between English/ the language of the colonizer and the native language of the colonized, then Joyce's literature affords an open and free space in which the relation between the two is simultaneously enacted in the text and absent from the text jumping not only from the traditional narratives that conceive the encounter of the colonizer and colonized as antagonistic but from the more tolerant approach that sees the colonizer and the colonized as mutually constitutive to a revolutionary stance that positions the colonizer and the colonized in a universal and cosmological system.

The issue of language is directly addressed in A Portrait where Stephen ponders over his ambivalence towards the English and native language alike. When conversing with the English dean of studies at his university in English, he ponders: 
The language in which we are speaking is his before it is mine. How different are the words home, Christ, ale, master, on his lips and on mine! I cannot speak or write these words without unrest of spirit. His language, so familiar and so foreign, will always be for me an acquired speech. I have not made or accepted its words. My voice holds them at bay. My soul frets in the shadow of his language. (Joyce, 1992, p.146)

Stephen's soul that "frets in the shadow of" English is akin to Yeats's being “eaten" by the English language. Both writers as colonized subjects acknowledge a deep-seated unrest with the use of a language that is not theirs, yet at the same time working within that language to invent a tradition. Stephen in an attempt to fight the hegemony of the English dean, "this courteous and vigilant foe" (Joyce, 1992, p.146), uses the word "tundish" that the latter has "never heard of" instead of "funnel" which is common in the imperial English (Joyce, 1992, p.145). As a matter of fact, "Irish was for [Joyce] no longer a feasible literary medium, but a means whereby his people had managed to reshape English, to a point where their artists could know the exhilaration of feeling estranged from all official languages" (Kiberd, 1996, p.331). Joyce celebrates hybridity in language and culture because it reflects the hybrid reality of modern Ireland.

Language besides religion and nationality "are nets flung at [the soul of a man born in Ireland] to hold it back from flight" (Joyce, 1992, p.157). Joyce, like Stephen, his autobiographical character, "shall try to fly by those nets" (Joyce, 1992, p.157) "using for [his] defence the only arms [he] allow[s] [him]self to use-silence, exile and cunning" (Joyce, 1992, p.191). Silence invokes observation and contemplation but above all it is an abstention from speech, from a specific language per se. Exile in the Joycean philosophy is particularly interesting. His novel Ulysses, for example, when about Dublin is written in exile, namely in Trieste, Zurich and Paris. Linguistically speaking, Fritz Senn (2018) coins the word "Lexile" to refer to "displacement or foreigness or salient oddity... on the lexical aspect" (p. 137). Senn details multiple techniques that Joyce uses to exile language such as deviant terms, traces of origin, aberrant catalogues, textual transfers, black holes and others. Chief among lexiles, however, is the juxtaposition of different world languages undermining the centrality of the English language but also of other languages. Senn (2018) writes:

Stephen Dedalus is fond of recondite or foreign words, in "Proteus" particularly: German (nacheinander, nebeneinander), Latin (iniuria patiens), Italian, Greek (adiaphane, euge), French (Zut, nom de Dieu), Gipsy, cant, etc. They are plug-ins from alien, often remote, areas. In groping for the most appropriate verb, Stephen tries out a series in English, German/Yiddish, French and Italian: "She trudges, schlepps, trains, trascines her load" (U 3.392), aiming for the best effect. (p. 141)

Cunning in a linguistic context may be equated with Senn's notion of lexile because tampering with language is a dexterous skill that Joyce masters very well. Eugene O'Brien (2007) points to Joyce's transformation of "William Shakespeare" into "Patrick W. Shakespeare" in Ulysses, which he sees as "name ... transformed into trope, with a "turning away' ... from colonial associations into those of the post-colonial" (p. 167) and which "is symbolic of Joyce's project, namely the redefinition and pluralization of Irish identity" (p. 167). O'Brien later concludes that "Joyce sees the nominal troping of Patrick W. Shakespeare as a liberation from that sterile Irish-English binarism, and as a displacement of the language of empire into the empire of language" (p. 168). Of course, Joyce's literature is abundant of lexiles and cunning, which serve as a testimony to Joyce's cosmopolitanism. 


\section{Conclusion:}

The loss of the native language, therefore, is not a fact to be lamented, it rather demonstrates the capacity to profit from the loss in producing new narrative modes, in allowing traditionally-competing narratives to some degree to mingle and to even a greater degree to annul each other and be part of a universal and cosmopolitan system. It has granted post-colonial writers the possibility of experimenting with the language of the other, an experimentation whose multifarious techniques can invest the post-imperial language with extraordinary aesthetic and political power. Paradoxically, losing the native tongue marks a new departure for post-colonial literature that cuts with colonialist form of discourse catapulting its writers into the forefront of the modernist movements, into the modern age, into the age of globalization.

\section{References:}

[1] Achebe, C. (1975). 'The African Writer and the English Language', Morning Yet on Creation Day. Anchor Press.

[2] Ashcroft, B, Gareth Griffiths and Helen Tiffin. (2002). The Empire Writes Back: Theory and Practice in Post-Colonial Literatures. Routledge.

[3] Diop, D. (1956). 'Contribution to the Debate on National Poetry', Présence Africaine 6, 113 115.

[4] Fanon, F. (2004). The Wretched of the Earth, translated from the French by Richard Philcox. Grove Press.

[5] Hyde, D. (2015, August 27). "The Necessity of De-Anglicizing Ireland", The Revival of Irish Literature: Addresses by Sir Charles Gavan Duffy, KCMG, Dr. George Sigerson, and Dr Douglas Hyde. T. Fisher Unwin, 117-161.

https://ernie.uva.nl/upload/media/eb201b85e5cb00114d568245a59cc05f.pdf

[6] Joyce, J. (1992). A Portrait of the Artist as a Young Man. Wordsworth Classics.

[7] Kiberd, D. (1996). Inventing Ireland: The Literature of the Modern Nation. Vintage Books.

[8] Loomba, A. (1998). Colonialism/Postcolonialism, New Critical Idiom Series. Ed. John Drakakis. Routledge.

[9] O’Brien, E. (2007). “The Language of Empire and the Empire of Language: Joyce and the Return of the Postcolonial Repressed", Enemies of Empire: New Perspectives on Imperialism, Literature and History, Ed. Eoin Flannery and Angus Mitchell. Four Courts Press, 160-171.

[10] Senn, F. (2018). “Joyce in Terms of Lexile”, James Joyce: The Joys of Exile, Joyce's Studies in Italy, Ed. Franca Ruggieri, 137-151.

[11] Thiong'o, N. (1986). Decolonising the Mind: The Politics of Language in African Literature. Pen to Print.

[12] Yeats, W. B. (1961). Essays and Introductions. Macmillian. 
[13] ---. (1970). Uncollected Prose Vol 1. Ed. John P. Frayne. Macmillan; Columbia University Press.

[14] ---. (1980). Yeats: Selected Criticism and Prose, first published 1964. Pan Classics.

[15] ---. (1999). Autobiographies, ed. William H. O’Donnell and Douglas N. Archibald. Scribner. 